NBER WORKING PAPER SERIES

\title{
STRUCTURAL/FRICTIONAL AND DEMAND-DEFICIENT UNEMPLOYMENT IN LOCAL LABOR MARKETS
}

Harry J. Holzer

Working Paper No. 2652

\author{
NATIONAL BUREAU OF ECONOMIC RESEARCH \\ 1050 Massachusetts Avenue \\ Cambridge, MA 02138 \\ July 1988
}

This project was supported with a grant from the W.E. Upjohn Institute. Christine Tonnos provided research assistance. I have benefitted from discussions with Paul Chen, Dan Hamermesh and especially Ed Montgomery. This research is part of NBER's research program in Labor Studies. Any opinions expressed are those of the author not those of the National Bureau of Economic Research. 
NBER Working Paper \#2652

July 1988

\title{
STRUCTURAL/FRICTIONAL AND DEMAND-DEFICIENT \\ UNEMPLOYMENT IN LOCAL LABOR MARKETS
}

\section{ABSTRACT}

This paper uses data on unemployment rates and job vacancy rates to measure structural/frictional and demand-deficient components of unemployment rate differences across local labor markets. Data on occupational and industrial distributions of unemployed workers and vacant jobs, as well as on local wages, recent sales growth, Unemployment Insurance, and demographics are then used to help account for these components of unemployment across local areas.

\author{
Harry J. Holzer \\ Department of Economics \\ Michigan State University \\ East Lansing, MI 48824
}




\section{Introduction}

Economlsts frequently categorlze unemployment into frictional, structural and demand-deficlent components. Frictlonal unemployment generally refers to the normal moverent of Individuals into and out of jobs while structural unemployment refers to particular difficulties in this process, caused by "mismatches" of skill, locations, etc. Demand-deficlent unemployment, on the other hand, refers to a shortage of jobs relative to workers - i.e., an excess of labor supply over labor demand at given wages. Such an excess can result from cyclical factors and possibly from secular ones as well, such as persistent non-market-clearing wages.l

While these categories are falrly distinct conceptually, our abllity to distinguish them emplrically has been less successful. At least part of this difficulty lies in our uncertalnty over how these components should be measured. Analyses of aggregate movements over time have centered on calculations of the "non-accelerating inflation rate of unemployment" (NAIRU), though our ability to measure this rate from time-serles data when the rate itself has been changing over time has been limited. ${ }^{2}$ More recently, Lilien (1982) has focused on the varlance in employment growth across industries as a measure of structural unemployment induced by sectoral shifts. This Interpretation has been challenged by Abraham and Katz (1986), among others. A more direct measure of job avallabllity and therefore of demanddeflclencles is the job vacancy rate, whlch has been widely analyzed In Great Britaln and other $O E C D$ countries. But since these data are not regularly collected by the federal government in the U.S., they have not been used very extensively here in sorting out types of unemployment. Analyses of aggregate movements over time have sometimes used the Conference Board's Help-Wanted Index as a proxy for the trend in the aggregate-vacancy rate (e.g., Abraham and Katz (1986), Abraham (1987)). Aside from these studles, only Abraham 
(1983) has used actual survey data on job vacancies to decompose unemployment in the U.S. into its structural/fictional and demand-deficient components. In this study I use data on unemployment rates and vacancy rates to sort out structural/frictional and demand-deficient components of unemployment differences across local labor markets. A fairly large literature already exists on local and reglonal unemployment rates which stresses "equilibrium" differences between markets (e.g., Hall (1970), Reza (1978), Surphy and Hofler (1985)). These studies stress local differences in wages, amenities, transfer payments/Unemployment Insurance, and population demographics. Alternatively, studies focusing on "disequilibrium" differences (e.g., Marston (1985), Topel (1986), stress local demand shocks which may require migration across areas in order to re-establish equilibrium. Others have focused on different regional sensitivities to aggregate cyclical fluctuations (e.g., Brown (1978), Rones (1986)) in analyzing disequilibrium differences. While the "disequilibrium" components of unemployment clearly center on relative demand differences across areas, the "equilibrium" components generally contain both denand-based (due to wages) and frictional/structural elements (due to wages and other factors mentloned above). 3

In this study I will use a cross-sectional analogue of the aggregate "Beveridge Curve" (i.e., the unemployment rate-vacancy rate relationship) to estimate the structural/frictional and demand-deficient components of local unemployment rate differentials. I will then use data on the occupations and Industries of unemployed workers and job vacancies, local wages, UI payments, industries, sales growth, and demographics in trying to explain these components. This latter part of the analysis should help link this study to the "equilibrium - disequilibrium" literatures on this topic. Comparisons of results for different years will also shed light on how these relationships change over the aggregate business cycle. 
The vacancy data used for this analysis are computed from the Employment Opportunity Pllot Profect (EOPP) Survey of Firms in 1980 and a followup survey (by Gallup, Inc.) In 1982. These firms (about 5200 in 1980 and 3400 in 1982) are located in 28 local areas which were sites for the EOPP labor market experlments of 1979 and 1980. Of these areas, thirteen are SMSA's and the rest are groups of counties. The sites are heavily concentrated in the South and Midwest, though they cover a broad range of industrial and demographic characteristics. The list of sites appears in the tables of the Appendix at the end of the paper. Within sites, large and/or low-wage firms were over-sampled. However, sampling welghts appear in the data to correct for this.

Vacancy rates at the level of the firm have been used to calculate site-level rates. These have been merged with published census data on unemployment rates for the same local labor markets. The EOPP data are also used for the calculation of area wage premla, while the census data are used for occupational, Industrial and demographic data here. Finally, state-wide data on UI benefits from Department of Labor publfcations are merged with the varlous site-level data as well.

\section{The Model and the Data}

The relationship between unemployment rates and vacancy rates has been studied extensively in the "Beveridge Curve" framework, which relates the two aggregate rates as they move over the business cycle. This relationship was first examined empirically by Dow and Dicks-Mireaux (1958) for Britain, and theoretical formulations were developed by Holt and David (1966), Holt (1970) and Hansen (1970). More recent contributions within the search framework Include those of Jackman et.al. (1984) and P1ssarides (1985).

The standard theoretical treatinent of this relationship specifies a steady-state movement of Individuals into and out of unemployment that leaves 
total unemployment unchanged - i.e., inflows equal outflows. Inflows into unemployment represent exogenously determined separation (or turnover) probabilities per period while outflows represent job accession probabilities. The latter will, in turn, reflect the stocks of unemployed Individuals and racant jobs, thelr chances of contacting each other, and the chances that offers will be made and accepted. More formally thls can be writen as:

1)

$$
t E=b\left(s_{L} U\right)^{x}\left(s_{F} V\right)^{y}
$$

where E, U, and V are stocks of employed workers, unemployed workers, and vacant jobs respectively; $s_{L}$ and $s_{F}$ are worker and firm search intensities; $t$ is the turnover rate out of employment; and $b, x$, and $y$ are parameters of a Cobb-Douglas production function of job matches (1.e., offers and acceptances) for a set of workers and vacant jobs. Returns to scale ln matching thus reflect the sur of $x$ and $y .4$

Solving for the unemployment rate u we obtain

$$
u=\left(\frac{t}{b_{L} x_{s_{F}}^{y} y^{y}}\right)^{1 / x}
$$

where $v$ is the vacancy rate. 5 It $1 s$ clear that a tradeoff exists between unemployment and vacancy rates since:

$$
\frac{d u}{d v}=-\frac{y u}{x v} \quad<0 \text { or } \frac{d^{\ln } u}{d \ln v}=-\frac{y}{x}<0
$$

Changes in the level of labor demand relative to labor supply are captured by this tradeoff since

4)

$$
U \equiv L^{s}-E, V \equiv L^{D}-E
$$

where $\mathrm{L}^{\mathrm{D}}$ and $\mathrm{L}^{\mathrm{s}}$ represent the stocks of labor demand and supply respectively. Changes in search intensity, the matching technology or turnover, on the other hand, w111 shlft the unemployment-vacancy locus Inward or outward. Shifts in the locus thus represent changes in frictional and/or structural unemployment while movements along the locus capture demand-induced 
unemployment changes (of a cyclical or more general nature).

While this framework is generally used to analyze aggregate movements over time, it can also be used to consider a cross-section of local labor markets. If we hypothesize that a common matching function (characterlzed by the parameters $x$ and $y$ ) exists across local markets, then we can analyze unemployment and vacancy rate differences across these markets. As Roper and Jackman (1987) have shown, the distribution of rates across these markets will help to determine the position of the aggregate Beveridge Curve. Thus, greater dispersion across sites (or greater convexity in the function) will lead to outward shifts in the aggregate curve, as shown in Figure 1 . Greater dispersion reflects a greater geographic imbalance in unemploynent and vacancies across sites, which would imply greater "structural" unemployment in the aggregate. Similarly, the changes in unemployment and vacancies of these local markets over the business cycle will determine the movement of the two rates along the aggregate curve as well, as shown in Figure 2.

An empirical representation of such an unemployment vacancyrelationship In a cross-section of local labor markets is:

5)

$$
u_{k t}=\alpha+\beta v_{k t}+\alpha z_{k t}+\varepsilon_{k t}
$$

where $u_{k t}$ and $v_{k t}$ are unemployment and vacancy rates in local market $k$ at time $t ;$ and the $z_{k t}$ are variables which shift the unemployment/vacancy locus. The latter might include the determinants of search intensity and the curnover rate as well as the match technology in that market; i.e., anything which helps determine frictional and/or structural unemployment in that market. 6 Such variables should include measures of skills in the population, which might determine the productivity of the matching technology; demographic characteristics (e.g., age and sex), which might determine tumover; and transfer payments or Unemployment Insurance that might affect search Intensity. 7 
Figure 1

Local Unemployment-Vacancy Relationships:

The Effects of Rising Dispersion

on Aggregate Unemployment

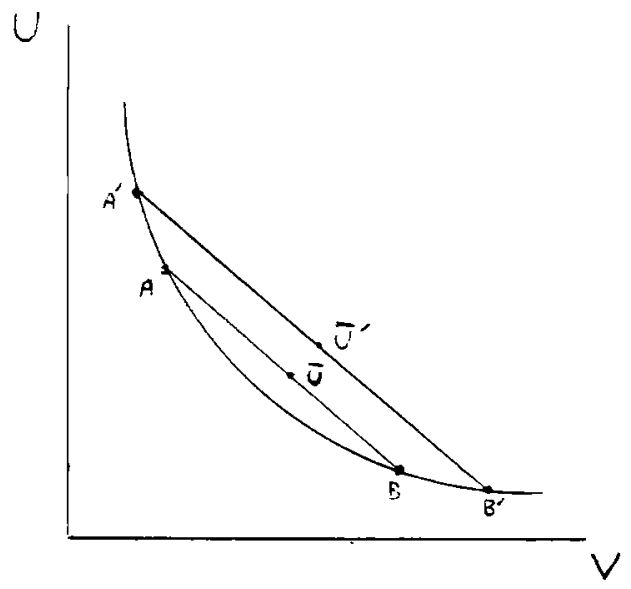

Figure 2

Local Unemployment-Vacancy Relationships: The Effects of the Business Cycle

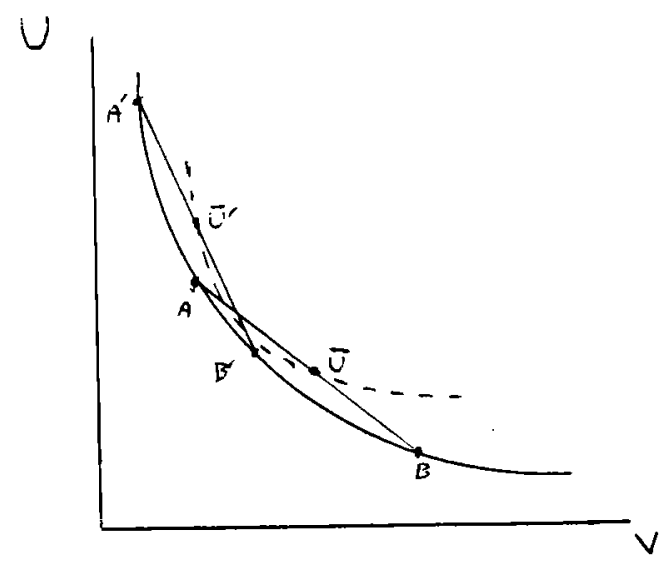


Anotine determinant of the match technology for each loial narket is the degree of balance between the occupational and indistrial distributions of enemployed rorkers and vacant jobs. Higher Imbalances suggest "mismatches" between the skills in which workers have invested and those needed for avallable jobs. Following Roper and Jackman, we estimate the degree of mismatch as:

6)

$$
I_{k}=.5 \sum_{i} j U_{1 k} / U_{k}-V_{1 k} / V_{k} j
$$

where $U_{i k} / U_{k}$ and $V_{i k} / V_{k}$ are the fractions of total unemployment and vacancies respectively in markets that are accounted for by occupation os Industry 1. These indices will therefore be included among the $Z_{k t}$ in solle variations of Equation 5 ).

In this context, $b * \sum_{k}\left(\nabla_{k t}-\nabla_{t}\right)$ would measure the variation in unemployment attributable to demand-shifts (or moveaents along the unemployment-vacancy locus) while $c * \sum_{k}\left(z_{k t}-Z_{t}\right)$ would reflect that part due to structural/frictional factors. Simple and partial $R^{2}$ 's should thus enable us to measure these components.

We can also add variables to Fquation (5) which might help to explain differences across local markets in relative labor demand - e.g., area wages, Industries, and/or sales growth. These variables will hopefully shed some light on the sources of these demand differences and perhaps on the Ir equilibrium/disequilibcium nature. Wages and industries might also contribute to the frictional and structural components of unemployment, since high average wages might themselves induce larger perlods of job search while industries might proxy for sklll requirements on the demand side of the labor market. Finally, we can estimate these relationships for different years to see how the components of unemployment differences change with the aggregate cyclical environment. 
4 few additional comments are in order concerning the estimation of this cross-sectional relationship. For one thing, the empirical functional form suggested by the Cobb-Douglas function is the double log (see Equation 3), of which the rectangular hyperbola is a special case. In our estimation below, we w111 consider several functional forms and check them for goodness of Eit.

Furthermore, the model presented above assumes that all markets are in a steady-state with constant unemployment and vacancy rates. While the nonsteady-state dynamics of aggregate markets have been $s$ tudied and even estimated on occasion, there is little which can be done to estimate such dynamics in a cross-section. 8 Consequently we will maintain the assumption that all markets are in their steady state, though the empirical implications of this being untrue will be considered. 9

Finally, we note that the vacancy rate and perhaps even some of the shift varlables (e.g., local wages and the age and education of labor force) In Equation (5) are endogenous. This equation does not have a particular casual interpretation; rather, it represents a locus of steady-state points determined by a combination of demand and structural factors whose effects we are trying to measure. Given this non-causal interpretation, the endogeneity of some independent varlables does not pose a severe problem.

We now move on to consider in greater detall the data with which Equation (5) above w111 be estimated. As mentioned before, we aggregate vacancy rates at the firm level in the EOPP data to obtain market-level rates. Vacancles are defined as all jobs which are avallable for lmmediate occupancy. Vacancy rates are defined as fractions of all fobs in these firms, whether fllled or vacant. However, vacancles in 1980 were gauged by the survey for non-managerlal and non-professional employees only. These employees are therefore onltted from the base group for that year as well. 
The unemployment rates as well as demographic and industrial data for each site were obtained from the City and County Data Book (1983), based on data from the 1980 Census. County-level data were weighted by population size in each case to obtain the appropriate variables for each site. The demographic variables which were used are the median age of the population, the fractions of the population aged 25 or more with high school and college degrees, and the fraction of the labor force that is female. The fractions of total employment found in manufacturing and in services for each market are also obtained from this source, whereas the fractions of unemployed workers in each occupation and industry (used for construction of the $I_{k}$ ) were found in the 1980 Census of Population for each state.10

The Unemployment Insurance measure used is the ratio of average weekly benefits to weekly wages, published state-wide by the Department of Labor.11 Unemployment rates for 1982 are published annual rates, using statewide averages for non-SMSA's. 12

Finally, certain variables for each site are calculated Erom the EOPP survey. The wage premia are the sample- and firm-size-welghted means of residuals from a log wage equation using the EOPP data. The wages used are starting wages for the last worker hired at each firm before the 1980 survey, while the controls are the age, education, prior experience and occugation of the worker hired. The sales growth measures are weighted means of the $\log$ of $(1+$ percentage sales growth) for the firms at each site between 1979 and 1981.13

\section{Eatinated Results}

In Table 1 we find a listing of all of the sites, along with their unemployment and vacancy rates in 1980. The results show that unemployment rates exceed vacancy rates in every local labor market in 1980 . On the other hand, substantial variation exists across sites in the ratio of vacancy rates 
Unemploynent and Vacancy Rates By Site, 1980

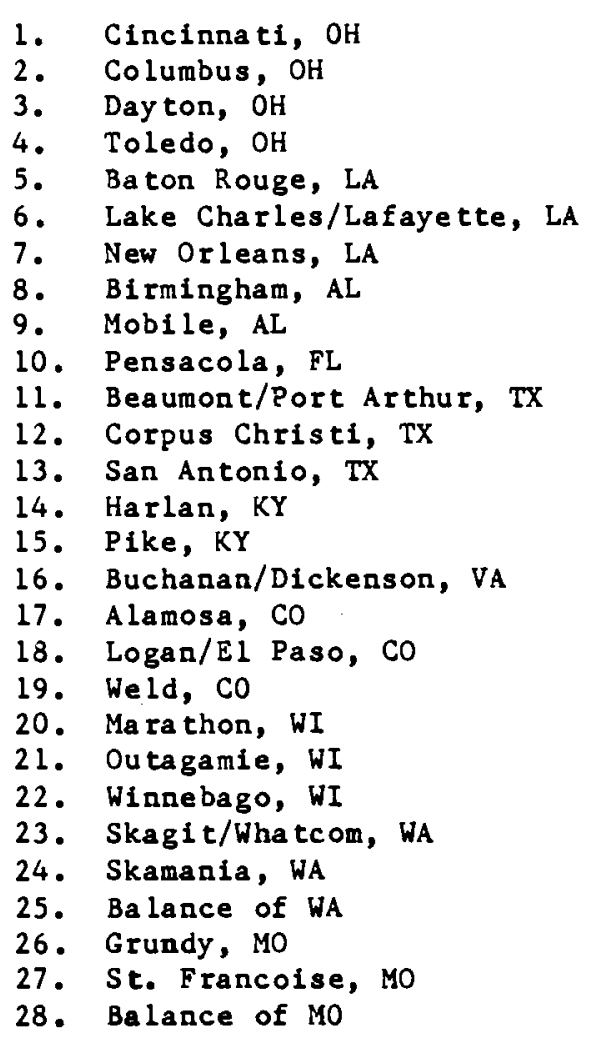

$\begin{array}{ll}u & v \\ .048 & .028 \\ .056 & .016 \\ .091 & .005 \\ .115 & .006 \\ .053 & .019 \\ .047 & .020 \\ .070 & .020 \\ .068 & .008 \\ .074 & .026 \\ .078 & .009 \\ .061 & .019 \\ .061 & .020 \\ .061 & .019 \\ .094 & .014 \\ .077 & .010 \\ .072 & .016 \\ .058 & .031 \\ .073 & .018 \\ .066 & .009 \\ .075 & .008 \\ .063 & .008 \\ .059 & .004 \\ .103 & .010 \\ .095 & .013 \\ .099 & .011 \\ .068 & .032 \\ .083 & .005 \\ .060 & .010\end{array}$


to unemployment rates. If we Interpret this ratio as the fraction of unemployment within each site that we can attribute to structural and fictional factors (while the remainder is attributable to deficlent demand), we see that this fraction ranges from as much as .583 (In Cincinnati) to as 11ttle as .046 (1n Toledo). We must, however, note that an excess of unemployed workers over vacant jobs does not by 1 tself signify a suboptimal market, since the cost of unemployment to individuals may be less than the costs of vacancies to firms. 14

In Table 2, Part A we present summary statistics on unemployment rates and vacancy rates for 1980 and 1982. Two different unemployment rates are presented. The first is based on the published rate for each relevent county from the 1980 census, while the second represents the annual averages for SMSA's and states (in place of non-SMSA's) for 1980 and 1982 . The former will be used below for most of the estimation in 1980, while the latter will be used only for comparisons of unemployment-vacancy relationships over different points in the business cycle.

These results show mean unemployment rates of about $7 \%$ in 1980 and $10 \%$ In 1982, which are approximately the annual averages for each of those years. 1980 thus represents a moderately healthy aggregate econony, while 1982 represents the trough of a major recession. Mean vacancy rates range from about $1.5 \%$ in 1980 to about $1.2 \%$ in 1982 . Unemployment rates therefore exceed vacancy rates by a substantial amount regardless of the economy's position in the business cycle.

However, we do observe the Inverse movements of the two rates as the aggregate demand for labor changes over the cycle. This is especlally clear when we consider the rates within the subsample of $\operatorname{SMSA}^{\prime} s$, which are based on large samples and are presumably measured with less error than those of the total sample. The aggregate economy, and 1ndividual local markets, thus 


\section{Table 2}

Unemployment and Vacancy Rates

1n 1980 and 1982:

A. Means and Standard Deviations

TOTAL

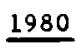

Unemployment Rate ${ }^{1}$

Unemp loyment Ra te ${ }^{2}$

Vacancy Rate

\section{(2)}

1982

SMSA's

\begin{tabular}{|c|c|c|c|c|}
\hline & 1980 & $\underline{1982}$ & 1980 & 1982 \\
\hline Unemployment Rate ${ }^{l}$ & $\begin{array}{l}.068 \\
(.018)\end{array}$ & - & $\begin{array}{l}.066 \\
(.018)\end{array}$ & - \\
\hline Unemp loyment Ra te ${ }^{2}$ & $\begin{array}{l}.070 \\
(.012)\end{array}$ & $\begin{array}{l}.101 \\
(.022)\end{array}$ & $\begin{array}{l}.070 \\
(.013)\end{array}$ & $\begin{array}{l}.101 \\
(.023)\end{array}$ \\
\hline Vacancy Rate & $\begin{array}{l}.015 \\
(.008)\end{array}$ & $\begin{array}{l}.012 \\
(.008)\end{array}$ & $\begin{array}{l}.016 \\
(.008)\end{array}$ & $\begin{array}{l}.011 \\
(.005)\end{array}$ \\
\hline
\end{tabular}

NOTE: Unemployment Rate ${ }^{l}$ is the pubilshed rate for each site based on the 1980 Census, while Unemployment Rate ${ }^{2}$ is the annual average for SMSA's and for states Instead of non-SMSA's. Vacancy rates for each market are calculated from the 1980 and 1982 EOPP Surveys. Means are weighted by labor force size of each market.

B. Unemp Loyment - Vacancy Equations, 1980 and 1982

1. Using Site-Specific Unemployment

\begin{tabular}{llll} 
& \multicolumn{2}{c}{$\frac{1980}{\text { TOTAL }}$} & SMSA \\
Ln (Vacancy Rate) & $\frac{-.234}{(.070)}$ & $(.090)$ \\
$\mathrm{R}^{2}$ & .299 & .571
\end{tabular}

2. Using SMSA and State-wide Annual Averages

1980

1982

$\begin{array}{lllll} & \text { TOTAL } & \text { SMSA } & \text { TOTAL } & \text { SMSA } \\ \text { Ln (Vacancy Rate) } & -.132 & -.173 & -.241 & -.418 \\ R^{2} & (.049) & (.081) & (.050) & (.088) \\ & .216 & .295 & .472 & .674\end{array}$

NOTE: Standard errors appear in parentheses. Equations (here and in all tables) are estimated using Weighted Least Squares, using (labor force size) $1 / 2$ as welghts. The dependent varlable is Ln (Unemployment Ritit). 
appear to be noving along their respective "Beveridge Curves" as aggregate demand declines.

In Table 2, Part $B$ we consider estimates of simple unemployment ratevacancy rate equations across sites. The first set of equations presents results using the Census-based unemployment rates for each site in 1980, while the second set presents results using the published SMSA and statewide data for 1980 and 1982. The equations are estimated ising Weighted least Squares to correct for potential heteroscedasticlty, where the weights are the square root of labor force size for each site. Both unemployment rates and vacancy rates appear in log form, which generally provided the best fits (though quadratic outperformed linear in all cases). 15

The results of Table 2 show that differences in vacancy rates account for substantial fractions of the total variation in unemployment rates across local markets (as measured by $R^{2}$ ). In Panel $A$, we see that the vacancy rate accounts for about $30 \%$ of the total varlation in unemployment. Within the sample of SMSA's this fraction rises to about 57\%. Estimated elasticities of unemployment with respect to vacancies also rise from about -.23 to -.34 . If vacancy rates are measured with less error among the SMSA's, 16 these results Imply that labor demand differences (relative to labor supply) gight account for as much as half or more of the unemployment rate differences across local labor markets.

The evidence of measurement error in vacancy rates among smaller sites led us to also consider the possible use of instruments for that variable. Two-stage least-square estimation of this equation was therefore attempted here. Using all of the $X_{k t}$ variables as well as wage premia and industrial employment as linstruments, the two-stage estimates were comparable in magnitude to the OLS estimates for the SMSA sample, though their precision and explanatory power were lower (coeffictent $=-.301$, standard error $=.102$, 
$\left.\mathrm{R}^{2}=.249\right)$. A simple hausman test on the significance of the instrumented vacancy rate led us to drop it from the subsequent analysis. ${ }^{17}$

The beter fit achleved from nonliaear functional forms relative to linear ones also suggests that major shlfts in labor demand across markets could have 1mplications for aggregate unemployment rates, since these rates may rise more when demand declines than they fall when demand rises. Since demand shifes across areas may have risen in frequency during the 1970's, the convexity of the estimated unemployment-vacancy relationships might have contributed to the observed shifting out of the aggregate "Beveridge Curve" during that decade. (See Abraham (1987), Holzer (1988).)

The comparison of unemployment-vacancy equations between 1980 and 1982 In the second set of equations shows a weaker effect for 1980 than appeared in the first set, when only site-specific unemployment rates were used. Nonetheless, we find a substantial rise in the magnitude of the demand effect between 1980 and 1982 . About $47 \%$ of the unemployment variation is accounted for by vacancies in the total sample, and over $67 \%$ is accounted for within the SMSA sample. These fractions are more than twice the magnitudes observed for 1980. The coefficients on the vacancy variables rise by comparable magnitudes.

These results Indicate that relative labor demand becomes a more cruclal determinant of unemployment rate differences across local markets when the aggregate economy enters a cyclical downturn. The larger estinated effects are also consistent with a movement of the aggregate economy to a new position along a convex Beveridge Curve, as predicted by the model above and as Indicated in Figure 2, Of course, the rise in the estimated coefficient on vacancies Indicates that the logarithic form may not be the correct one here, though it provides the best avallable approximation. 18 
While the estimates of Table 2 provide a glimpse at the importance of demand differences in explaining unemployment, we need to control for factors that determine structural and frictional unemployment as well.19 Several estimates are presented in Table 3. Among the control variables we include our Lndices of occupational and industrial imbalance between unemployed workers and vacant jobs. Other control variables are chosen to reflect the demographic factors and transfer programs which should be the most important determinants of job turnover and search durations. They are also nost frequently mentioned as potertial causes of the outward shifts in Beveridge and Phillips Curves in the $1970^{\prime}$ s. $^{20}$ The demographic variables include the median age of the labor force and fraction which is female; while the program variables is the Unemployment Insurance benefit to wage ratio. We also include the fractions of the labor force with high school and college degrees, since education may be a proxy for skills and "matching" success in a local labor matket. Flially, we include geographic dumm variables (for South and SiYSA) in some equations to capture unmeasured effects of location and region of residence as frictional and structural characteristics.

Several specifications are presented in Table 3 , since the sample size is relatively small and independent variation across the list of regressors is not particularly high. Thus we generally include the geographic variables separately, siace they are highly correlated with college education and UI ratios. 21 Some specifications exclude median age, since younger people are most likely to migrate in response to demand factors captured by the unemployment-vacancy coefficient. The frictional and structural variables appear both with and without the vacancy rate, so that their effects on unemployment when controlling for labor demand can be gauged. But the firal specification (column 7) does lnclude all of these regressors. 


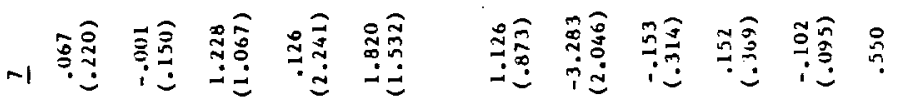

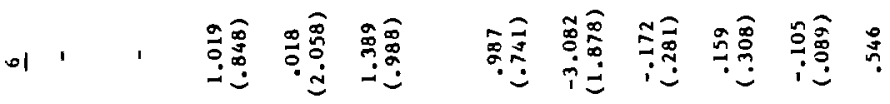

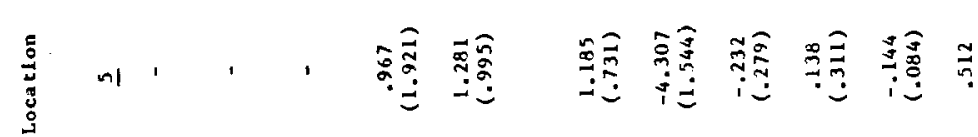

总

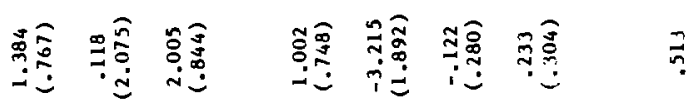

ํำ

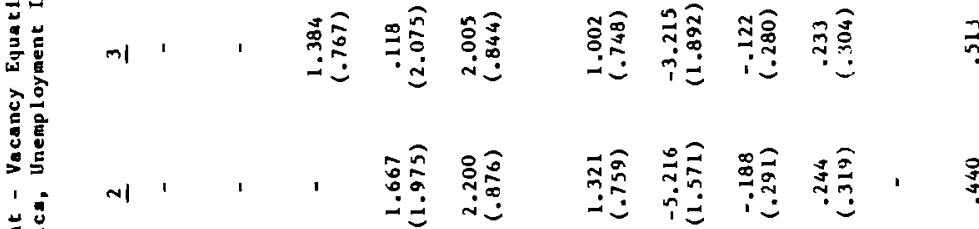

过

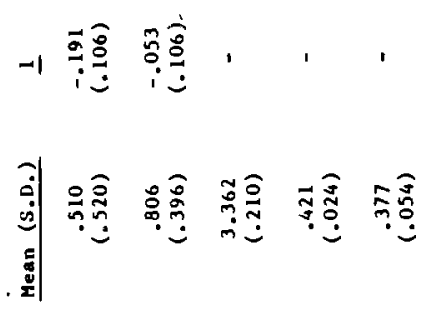

ํํำ

คิํํำ

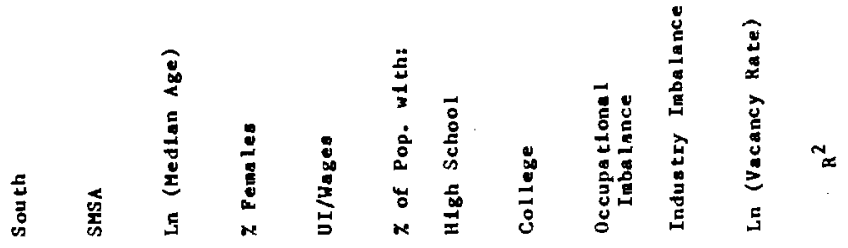

$\stackrel{3}{3}$ 
Several findings emerge from Table 3 . The significantly lower unemployment rate of the South which we observe in column 1 is largely accounted for by thelr higher vacancy rate (colunn 4) and also by certain other factors, such as lower UI benefit ratios. This later varlable has a significant positive effect on unemployment before controlling for vacancies and a marginally significant effect after controlling for them. The benefits of a college-edicated labor force in lowering unemployment also appear substantial, even after controlling for vacancies. Both variables thus appear to be capturing Erictional and/or structural effects on unemployment, and are consistent with findings in the literature (see Footnote 7).

On the other hand, nelther of our indices of imbalance between unemployed workers and vacat jobs contributes significantly to unemployment. Of the two measures, only the index for industrial imbalance has the correct $s 1 \mathrm{gn}$. These results are consistent with evidence from other countries (e.g., Britain in Roper and Jackman, Germany in Franz).

As for the effects of labor force age and gender on unemployment, we find that the fraction of females in the labor force has a positive but generally not signiflcant effect. Age, on the other hand, has a significant positive effect without the vacancy control and a maginal pusitive effect even with the control. Since younger workers (especially teens) are well known to have higher rates of frictional unemployment, this is peripas surprising. The age effect might therefore reflect the greater mobility and training of young workers in response to shlfting labor market opportunities, thereby lowering frictional/structural unemployment within a market. However, the age effect may also at least partly reflect endogenous migration responses across markets in response to demand-based unemployment differences. This last interpretation is supported by the relatively sharp decifine in the magnitude of the vacancy coefficlent when age is included. But even without 
controlling for age, the inclusion of Jemographics and UI varlables reduces the magnitude of the vacancy effect by over a third.

Finally, we note the ability of these equations to explain over half of the total variation in unemployment across all sites. Calculations of partial $R^{2}$ 's suggest that more than half of the explained variation is accounted for by the frictional/structural variables of Table 3.22

While these estimates give us some insight into the determinants of frictional and structural unemployment differentials, they give us little understanding of the forces driving the relative demand differences across local markets. In Table 4 we consider the effects of three potential determinants of relative demand differences: 1) Wage levels; 2) Industries; and 3) Recent shifts in product demand. As noted above, wage level differentials can create "equllbrium" differences in unemployment across local areas, though wages may themselves respond to high levels of unemployment caused by demand shifts. 23 Industrial differences can proxy for different cyclical sensitivities, wages, shocks to product demand or technology (both of which effect labor demand), as well as differences in skill requirements or other frictional and structural factors. 24 Demand shifts, measured by differences across markets in average sales growth, are most likely to reflect short-run "disequilibrium" causes of demand-based unemployment, 25

Once again, high correlations among regressors and small sample sizes cause us to estmate several different specifications of equations containing these variables. We therefore enter them separately in equations with and without the vacancy rate. 26

Columns 1-3 of Table 4 show fairly significant, positive effects of wages (as in Hall $(1970,1972)$ ) and manufacturing employment and negative effects of average sales growth on unemployment rates. Controling for 


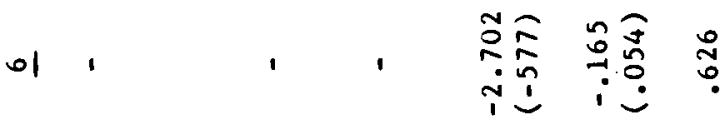

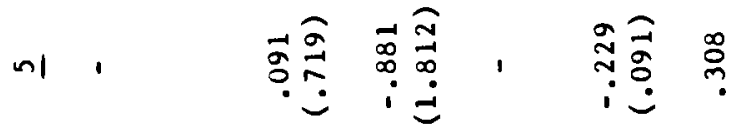

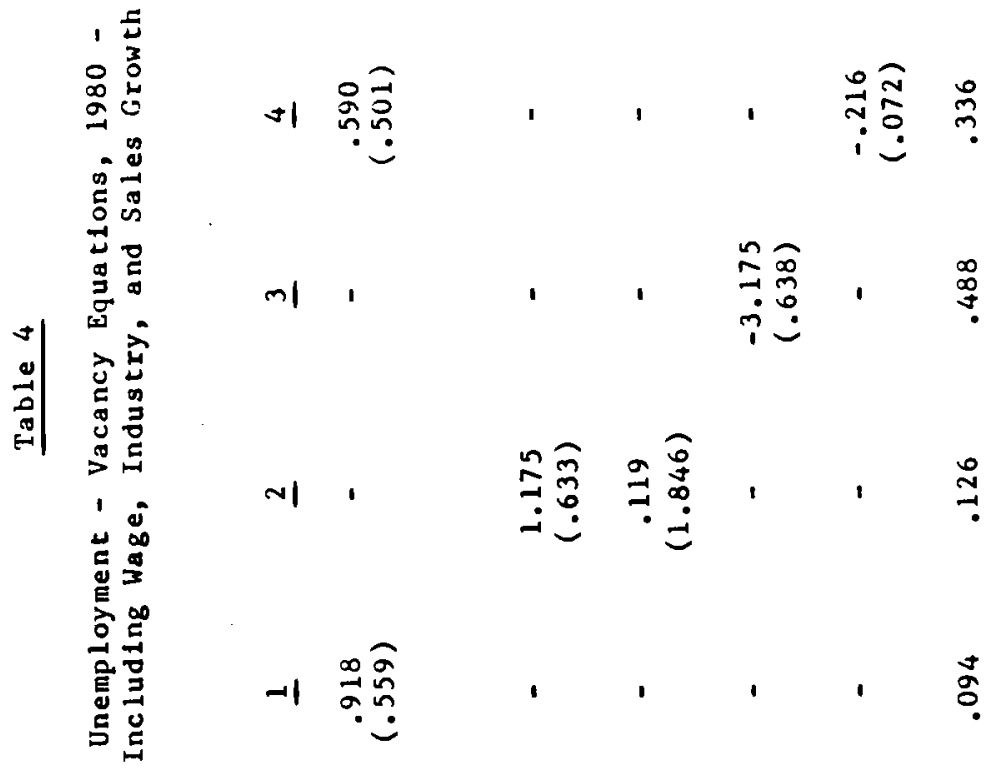

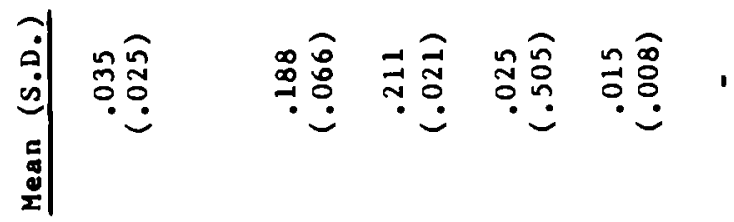

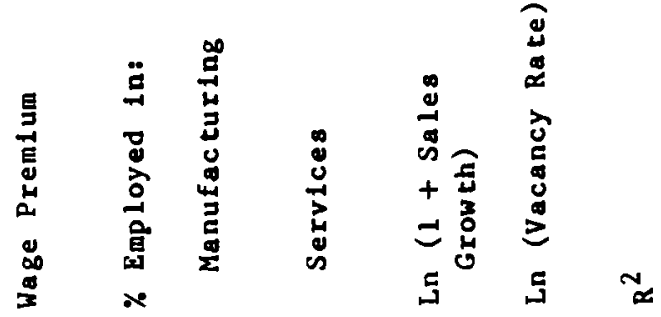

$\underset{0}{0}$ 
vacancies in column 4-6 reduces the magnitude of the wage coefficient by over a third and the manufacturing coefficient almost entirely, though the sales growth effect is reduced by less. These findings suggest that lower relative demand accounts for part of the wage effect and almost all of the manufacturing effect on unemployment.

A comparison of the vacancy coefficients of this table with those of Table 2, Panel A also shows that including wages or industry has litele effect on the vacancy coefficient while including sales grow th reduces that coefficient by about a third. It therefore appears as though recent demand shifts play a much greater role in explaining relative demand effects on unemployment than do wage differences or industrial compostions across local labor markets. These shifts presumably lead to wage and price adjustments within markets as well as migration between markets that should help to equalibrate those markets in the longer run. 27

\section{CONCLUSION}

In this study I use data on unemployment rates and vacancy rates to estimate the structural/frictional and demand-deficient components of local unemployment rate differentials. I then use data on demographics, UI benefit ratios, wages, industries and sales growth across these local markets in trying to account for these components.

The results of the paper show that demand deficiencies account for a substantial fraction of unemployment rate differentials. In 1980 this fraction might be as high as half or more for SMSA's, though the exact magnitude is unclear. The fraction also appeared to rise substantially during the major cyclical downturn of 1982. Within local markets, unemployment rates exceed vacancy rates by substantial amounts, though the ratios of the latter to the former vary widely across markets. 
The demand component of unemployment partially accounts for the higher unemployment of high wage areas and almost totally accounts for that of manufacturing areas. But wages and inanufacturing account for very little of the total demand component of unemployment. Recent shifts in product demand, measured by differences across areas in sales growth, appear to play a greater role In explaining the demand component of unemployment in the short-run.

As for the frictional/structural component, we find that UI benefit-towage ratios and fractions of the labor force with college degrees are major positive and negative determinants of this component respectively. While the fraction of females in the labor force had virtually no effect, the median age of the labor force contributed positively to unemployment. Some part of tie age effect, though not a 11, appeared to reflect a migration of young workers In response to differentlal. Finally, Indlces of occupational and industrial Imbalance between unemployed workers and vacant jobs had no sIgnificant effects on measured unemployment rates.

We must keep In mind some caveats of this study when reviewing the results. Measurement error seems to plague the vacancy rate, especially in the non-SMSA markets. Small sample slzes and high correlations among regressors limited our abllity to disentangle some of these effects. The exogenelty of certain regressors is also questionable.

St111, the results suggest that many factors contribute to uneaployment rate differences across areas. Pollcy attempts to reduce these differences must consider a broad range of these factors if they are to be successful. 


\section{FOOTNOTES}

This characterization of business cycles as demand-side gher. nena abstracts from other recent explanations of fluctuations, such as the literature on real business cycles (e.g., Long and Plosser (1983)) Evidence of the persistence of non-market-clearing wage differences across industries appears in Krueger and Summers (1986) but is disputed in Murplay and Topel (1987).

${ }^{2}$ For a recent analysis which questions the existence of a unique NAIRU see Blanchard and Summers (1986).

3 Wages differences can create changes in labor demand by movements along local demand curves, assuming uncovered sectors cannot absorb the labor displaced in the covered section (Mincer, 1976). High wages can also lead to queues for jobs or longer durations of search unemployment, thereby raising frictional/structural unemployment. Farly evidence on the persistenceof high wages and unemployment for certain SMSA's is found in the papers noted above by Hall.

4 This model essentially follows that of Holt and Jackman et. al. Their models are generalizations of earlier ones (e.g., Lipsey $(1960)$ ) in which $s_{Z}=s_{F}=x=y=1$. Thus increasing returns are suggested in these earlier models while the later ones consider the posstbility of constant (or decreasing) returns. More general functions are lso considered in Jackman et. al. and Franz (1986).

5 Unemployment and vacancy rates are defined as $u=U / E$ and $v=V / E$ respectively.

${ }^{6}$ Equation 2) Inglies that the structural parameters $x$ and $y$ (and therefore returns to school) of the matching function could be estimated if turnover rates and search intensities could be measured. Using firmwide 
measured of tibese riables that are available in the EOPP data, I attempted to estimate these parameters. Jnfortunately, the estimates were extremely unstable ail we therefore abandoned.

7Evidence that Unemployment Insurance affects search Intensity directy can be found In Barron and Mellow (1979). Effects of Unemployment Insurance on reservation wages and unemployment duration are observed in Moffitt and Nicholson (1982) and Ehrenberg and Oaxaca (1976), anong others. Demograpinic effects on turnover rates are found in Marston (1976). Age, sex, and education effects on unemployment are t lso recently discussed In Summers (1987).

8 Dynamics can be considered if Equation (1) is modified to be

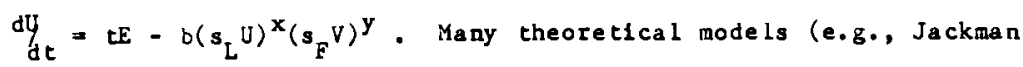
et. al, Pissarides) suggest that these dynamics involve a counterclockilse novement between steady-state points on the Beveridge Curve. Emplrical estimates of model parameters in a dynamic context can be Eound for Britain in recent papers by Duffy (1983) or Hannah (1984).

${ }^{9}$ The possibility that observed unemployment and vacancy rates are non-steadystate is enhanced in local labor markets by the prospects of migration across areas in response to demand and supply shocks. Given the high rank correlations in unemployment rates over time for local areas (Hall, 1970), the ability of migration to rapidly eliminate unemployment differentials seems falrly low.

10 Occupational and Industrial distributions of unemployment are calculated as the differences in distributions for the experienced labor force and the employed. The former are avallable only for the categories of rural and non-rural within each state. Consequently each index is calculated twice per site: once using statewide unemployment data, and once using rural data for non-SMSA's and non-rural data for SMSA's within each 
state. Results for each are reported below for the second version, though they were extremely comparable.

11 See Unemployment Insurance Financial Data, United States Department of Labor, Employment and Training Report No. 394 (1983).

12 Annual rates for both states and SMSA'a are published in the appropriate Issues of Employment and Earnings. Comparisons between 1980 and 1982 rates are only made using rates that are similarly constructed for the two years.

${ }^{13}$ The 1982 survey asked, "Adjusting for price increases, approximately what was the percentage change in your unit sales [between 1979 and 1981]?"

${ }^{14}$ See the discusston by :1incer in the NBER volume on vacancies (1966).

$15_{\text {Adjusted }}{ }^{2}$ was highest for the logarithic form in all cases except when using the mix of SMSA and statewide rates Eor 1980, where the quadratic form gave the best fit. In all cases the quadratic tem was positive and at least marginally significant, thus providing a better fit than did the linear form.

${ }^{16}$ The magnitude of measurement ecror can be gauged by using the reciprocal of the coefficient from a reverse regression to estimate the upper bound to the true coefficient estinate. Doing so gives upper bounds of -.785 for the total sample and -.605 for the SilSA sample. Given that the directly estimated coefficients are lower bounds which are -.234 and -.345 respectively, we see a wider range and thus potentially more error within the total sample.

${ }^{17}$ An unemployment equation containing both the orfginal and instrumented versions of the vacancy rate produced coefficients and standard errors of -.166 and .101 on the original as well as -.135 and .141 on the instrumented rate.

${ }^{18}$ The significantly higher slope (though the intercepts are almost identical) 
for 1982 is unlikely to represent a shift in the curve, since only two years separate the cross-sections. The likelihood that a single aonlinear functional form exists for these two estinates which is not well-measured here therefore is high. Alternatively, certain markets in one or both of these years might reflect non-steady-state movements between points on stable Beveridge Curves for those particular markets.

${ }^{19}$ The signiflcantly different estimated coefficients across the two years, as we 11 as the evidence of measurement error in the vacancy rate cited above, also precluded the use of first difference estimators here and below In dealing with problems of omitted varlables. The exacerbation of measurement error problems in first-difference or fixed-effect models 13 discussed in Freeman (1984). First-difference estimates were substantally lower in magnitude and explanatory power than were the OLS estinates of either year.

${ }^{20}$ See Abraham ( 1987 ) for a recent discussion of these shifts in the U.S. and Jackman et. al. (1984) for one ln BritaIn.

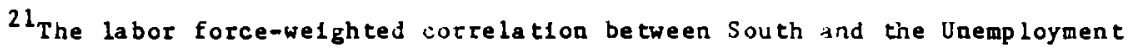
Insurance ratio is -.76 , while that between UI ratio and college education is . 52 .

22 When the vacancy rate i.s sonsldered the first varlable entered, the partial $R^{2}$ (based on column 5 of Table 3) for the frictional/structural varlables is approximately. 30 , which is comparable to the simple $R^{2}$ for vacancies in Table 2B. When the Erictional/structural variables are entered first (using columa 2 of Table 3 ), the partial $R^{2}$ for vacancies Is reducert to .23 .

${ }^{23}$ Medoff (1983) and Holzer (1987) for more general evidence of unemployment effects on wage Increases across areas. 
${ }^{24}$ See Krueger and Sunners $(1986)$ for evidence on industry wage differentials and Pencavel (1970) for quit differentials ascoss Industries.

${ }^{25}$ The interprecation of average sales growth differences as demand shifts across markets, as well as their effects on unemployment, are discussed at great length in Holzer (1988).

${ }^{26}$ These equations were also estimated with and without the inclusion of demographic and Unemployment Insurance variables. Most results were fairly similar, although employment in the service industry siowed a significant positive effect on unemployment when the extra controls were included. Once again, high correlations between Unemployment Insirince, college education and industry made precise estimates of effects quite difficult to achleve.

${ }^{27}$ See Greenwood (1975), Ledoff (1983), Topel (1986), and Marston (1985), for discilsions and evidence on these varlous adjustnents to labor denand shifts across areas. 


\section{REFERENCES}

Abrahain, Katherine. "Structural/Frictional v. Deficlent Demand

Unemployment: Some New Evidence," American Economic Rev1ew, September 1983.

Abrahain, Katherine. "Help-Wanted Advertislng, Job Vacancles, and

Unernployment," Brookings Papers on Economic Activfty, 1987:1.

Abrahar, Katherine and Lawrence Katz. "Cyclical Unemployment: Sectoral

Shifts on Aggregate Disturbances?" Journal of Polltical Economy, Iind, 1986.

Barron, John and Wesley Mellow. "Search Effort 1n the Labor Market." Journal of Human Resources, 1979.

Browne, Lynn. "Reglonal Industry Mix and the Business Cycle," New England Economic Review, July-August, 1978.

Blanchard, 0 and Lawrence Suraners. "Hysteresis and the European Unemployment Problem." NBER Macroeconomlcs Annual, 1986.

Dicks, L.A.-MIreaux, and J.C.R. "The Excess Deinand for iabour: A Study of Conditlons in Great Britala, 1946-56." Oxford Economlc Papers, 1953.

Duffy, M.H. "The Relationshlp between Unemployment and Vacancies In Great Brita1n: An Extended Job Search, Labour Turnover View." Bulletin of Econom1c Research, 1984.

Ehrenberg, Ronald and Rontil Daxaca. "Unemployment Insurance, Unemployment Durations and Subsequent Wage Growth." American Economic Review, 19.76. Franz, Wolfgang. Match or Mlsmatch? The Anatomy of Structural/Frictional Unemployment In Germany: A Theoretical and Empirical Investigation." Unfversity of Stuttgart, 1986.

Freeman, Richard B. "Longltudinal Analyses of the Effects of Trade Unions." Journal of Labor Econorics, January 1984. 
Hall, Robert. "Why is the Unemployment Rate io High at Full Employment?" Brookings Papers on Economic Activity, 1970.

Hannah, S.P. "Cyclical and Structural Determinants of the IV Relationship." Applied Economics, 1983.

Hansen, Bent. "Excess Demand, Unemployment, Vacancies, and Wages." 2uarterly Journal of Economics, February 1970.

Holt, Charles. "How Can the Phillips Curve Be Moved to Reduce Both thelation and Unemployment?" In E.S. Phelps ed. Microeconomic Foundations of Enploypent and Inflation Theory. (1970)

Holt, Charles and Yartin David. "The Concept of. Job Vacancies in a Dynamic Theory of the Demand for Labour," th The Measurement add Interpretation of Job Vacancies, National Bureau of Economic Research, 1966. Holzer, Harry J. "Unenployment Rates and Denand Shifts in Local Labor Markets." Unpublished paper, 1987.

Jackman, Richard, et. al. "On Vacancies." Discussion Paper 165, London School of Economics, Center for Labour Economics, August 1984. Jackman, Richard and Stephen Roper. "Structural Unemployment." Oxford Bulletin of Economics and Statistics, 1987.

Krueger, Alan and Lawrence Summers. "Efficlency Wages and the Wage Structure." NBER Working Paper, 1986.

Lilien, David. "Sectoral Shifts and Cyclical Unenployment." Jourmal of Political Economy. July, 1982.

Lipsey, Richard. "The Relationship between Unemployment and the Rate of Change of Money Wage Rates in the United Kingdom, 1862-1957: A Further Analysis." Economica, February 1960.

Long, John and Charles Plosser, "Real 3islness Cycles." Journal of Political Economy, February 1983. 
Marston, Stephen. "Two Views of the Geographic Distribution of Unemployment," Quarterly Journal of Economics, February 1985.

Marston, Stepizen. "Employment Instability and High Unemployment Rates." Brookings Papers on Economic Activcity, 1976:1.

Yedoff, James. "U.S. Labor Markets: Inbalance, Wage Growth, and Productivity In the 1970's," Brookings Papers on Economic Activity, 1983:1.

Mincer, Jacob. "The Economics of Wage Floors." Journal of Political Economy, 1976.

Mitchell, Danlel. "Shifting Norms in Nage Determination." Brookings Papers on Economic Activity, 1985:2.

Moffitt, Robert and Walter N1cholson. "The Effects of Unemploynent Insurance on Unemployment: The Case of Federal Supplemental Benefits," Review of Economics and Statistics, February 1982.

Murphy, Kevin J. and Richard Hofler. "Determinants of Geographic Unemployment Rates: A Selectively Pooled-Simultaneous Model." Review of Economics and Statistics, May 1984.

Murphy, Kevin M. and Robert Topel. "Unemployment, Risk and Earnings." in Unemployment and the Structure of Labor Markets. ed. by K. Lang and $J$. Leonard. Basil Blackwell, 1980.

Pencavel, John. An Analysts of the Quit Rate in American ianufacturing

Industry. Princeton University, 1970.

Pissarides, Christopher. "Short-Run Equilibrium Dynamics of Unemployment,

Vacancies, and Real Wages." American Economic Review, September 1985.

Reza, A11. "Geographical References in Earnings and Unemployment Rates,"

Review of Economics and Statistics, May 1978.

Rones, Philip. "An Analysis of Regional Employment Growth, 1973-85," Monthly Labor Review, July 1986. 
Summers, Lawrence. "Why Is The Unemploynent Rate High Near Full

Employment?" Brookings Papers on Economic Activity, 1986:2.

Topel, Robert. "Local Labor Markets." Journal of Politiby R Ronomy, June 1986.

Topel, Robert. "On Layoffs and Unemployment Insurance." American Economfc Review, September 1983.

United States Department of Labor, Employment and Training Handbook io. 394 , 1983. 